\title{
Den konstanta oron
}

\section{Barns och ungas psykiska ohälsa i svensk dagspress \\ 1968-2008}

Peter Skagius \& Karin Zetterqvist Nelson

Psykisk ohälsa bland barn och unga har under de senaste åren återkommande framställts i svensk dagspress som ett tilltagande samhällsproblem. ${ }^{\mathrm{I}}$ Under 2016 redogjorde exempelvis dåvarande utbildningsminister Gustav Fridolin (MP) i Dagens Nyheter för hur Sverige "aldrig varit rikare, men våra barn mår allt sämre". ${ }^{2}$ Ett år senare varnade flera forskare, med hänvisning till en nyligen publicerad rapport från Socialstyrelsen, för en "dramatisk" ökning under de senaste tio åren av psykisk ohälsa bland barn och unga. ${ }^{3}$ Dessa två exempel på hur barns och ungas psykiska hälsa diskuterats och problematiserats i media av forskare, professionella och myndigheter illustrerar det sätt varpå budskapet ofta ramats in och förmedlats. Med nuet som normativ utgångpunkt har utvecklingen värderats i dystopiska termer - "det har aldrig varit värre än vad det är i dag!" - vilket i sin tur motiverat moraliskt laddade krav på akuta insatser - "någonting måste göras!"

Denna problembeskrivning framstår emellertid som alltför nutidscentrerad och ahistorisk när den ställs mot den psykiatri- och psykologihistoriska forskning som påvisat dessa discipliners föränderlighet över tid och rum, såväl begreppsligt som i deras påverkan på vardagliga uttryck för psykisk sjukdom och lidande och på hur människor uppfattar sig som psykologiska subjekt. ${ }^{4}$ Den offentliga diskussionen om barns och ungas psykiska ohälsa har i det närmaste helt förbisett sådana historiska aspekter på de psykologiska och psykiatriska disciplinerna. Samtidigt har den historiska forskningen, som annars varit drivande i att belysa vetenskapernas historicitet, inte tagit sig an frågan om svenska barns och ungas psykiska ohälsa i media. Denna samhällsrelevanta fråga har med andra ord varit eftersatt såväl teoretiskt som empiriskt.

Med denna artikel vill vi bidra till att åtgärda denna brist genom att analysera hur svenska barns och ungas psykiska ohälsa - vilken vi, i linje med de resonemang som presenteras nedan, konceptualiserar som ett vetenskapligt och offentligt objekt - cirkulerat i den svenska dagspressen under åren 1968-2008. Vi intresserar oss för vilka former av expertis, inklusive centrala termer och begrepp, som varit betydelsefulla för artikulerandet av barns och ungas psykiska ohälsa, vilka rapporter och undersökningar som 
hänvisats och vilka aktörer som varit delaktiga i diskussionerna. Därutöver vill vi lyfta vad dessa diskussioner kan ha haft för betydelse för läsare, exempelvis gällande hur barn och unga bör förstå sin egen, presumtiva, psykiska ohälsa. Därigenom kan studien bidra till en bättre förståelse av de barnpsykologiska och -psykiatriska disciplinernas historia samt skänka viktiga infallsvinklar på den i dag pågående diskussionen om barns och ungas psykiska mående.

Teoretiskt stödjer vi oss på vetenskapshistorisk och -sociologisk forskning som argumenterat för att media och vetenskaperna inte ska ses som separata sfärer där media endast är en arena för att sprida resultat producerade i exempelvis laboratoriet. ${ }^{5}$ Bland annat har vetenskapshistorikern James A. Secord framhållit vikten av att studera kunskap i rörelse (knowledge in transit) eftersom hur kunskap förflyttas och översätts över tid och rum enligt honom utgör en grundläggande, snarare än perifer, del av vetenskaperna. ${ }^{6}$ En grupp nordiska forskare har likaså betonat värdet av att studera cirkulationen av kunskap och dess reception bland olika publiker. En av dessa är historikern David Larsson Heidenblad som påpekat att detta inbegriper en förskjutning $i$ analytiskt fokus, från att exempelvis studera själva innehållet i en inflytelserik bok till att fokusera på hur (ofta specifika delar av) boken har cirkulerat i offentligheten. ${ }^{8}$ I denna artikel lutar vi oss mot deras nyckelbegrepp kunskapscirkulation för att understryka att vårt analytiska intresse är riktat mot hur exempelvis vetenskapliga rapporter om barns och ungas psykiska ohälsa använts och hänvisats i svensk dagspress, i stället för mot rapporternas faktiska innehåll.

Men som bland andra den medicinska antropologen Charles L. Briggs tillsammans med medieforskaren Daniel C. Hallin poängterar är media inte "bara" en arena för cirkulationen av kunskapsanspråk. Det är även en plats som möjliggör för medie- och hälsoaktörer att (sam)producera vetenskapliga ontologier. ${ }^{9}$ Deras perspektiv bryter ännu tydligare med den traditionella bilden där vetenskapliga objekt och fakta skapas på en plats för att sedan "populariseras" via media till en passiv publik. ${ }^{\mathrm{IO}} \mathrm{I}$ Briggs och Hallins läsning är det i stället mer rättvisande att se relationen mellan media och vetenskaperna som "a border along which new [...] objects and subjects - and the way we come to know and talk about them - are produced". Detta synsätt knyter väl an till den historiska forskning som betonat hur psykologins och psykiatrins teorier och praktiker påverkat hur individer förstått och agerat gentemot sig själva som psykologiska subjekt. Den psykologi- och psykiatrihistoriska ansatsen kan tillsammans med den medieteoretiska förståelse som Briggs och Hallin representerar utgöra ett meningsfullt analytiskt ramverk för studier i skärningspunkten mellan media och de psykologiska och psykiatriska disciplinerna. Ramverket kan belysa hur betydelsefulla 
aspekter av psykologins och psykiatrins historicitet och samhällsroll varit sammanbundna med media och hur de tillsammans möjliggjort en bred cirkulation av psykologisk och psykiatrisk expertis.

\section{Historisk forskning om svensk barnpsykologi och -psykiatri}

Psykologi- och psykiatrihistorisk forskning har synliggjort hur det skett relativt stora förändringar över tid i hur mental (o)hälsa definierats och klassificerats och hur detta varierat mellan geografiska kontexter och kulturella sammanhang. ${ }^{\text {II }}$ Vad som utgör psykisk ohälsa, vad som är dess orsaker och hur den ska behandlas har således skiftat beroende på vart man riktat blicken och vilken tidsperiod som stått i fokus. Detta har lett forskare till att tala om ohälsa i termer av bland annat "kultursjukdomar" eller "ekologiska nischer", för att understryka att olika former av ohälsa uppstår, florerar och vidmakthålls i specifika sammanhang. ${ }^{\text {I2 }}$ Ett empiriskt exempel ur den svenska kontexten har getts av idéhistorikern Maria Björk som visat hur den neurosdiskurs som var dominerande i Sverige under 1950-talet gradvis övergick till en diskurs om stress där den etiologiska emfasen försköts från individens tillkortakommanden och "konstitutionella svagheter" till miljöns starka påverkan. ${ }^{13}$

Medan barnpsykologin och -psykiatrins historia inte är lika beforskad har ändå liknande utvecklingar och tendenser kunnat urskiljas. I Sverige har i synnerhet historikern Roger Qvarsell studerat hur den svenska barnpsykiatrins etablering under det tidiga 1900-talet skedde parallellt med att vissa "barnrelaterade" problem började bli omdefinierade som medicinska problem som kunde behandlas av barnpsykiatrisk expertis, i stället för att ses som uttryck för exempelvis bristande moral. ${ }^{14}$ Institutionellt sett var det sedan de mentalhygieniska tankegångarna, med deras betoning på prevention och öppna vårdformer, som blev mest inflytelserika för den tidiga barnpsykiatrins utformning. ${ }^{{ }^{55}}$ Dock var det terapeutiska landskapet även starkt influerat av den psykoanalytiskt inspirerade Ericastiftelsen som etablerades under 1930-talet och som sedan utvecklades i nära samverkan med den offentliga psykiska barna- och ungdomsvården. ${ }^{16}$

Svenska historiker har skildrat hur barnpsykologisk och -psykiatrisk expertis fick en ökad betydelse under de följande decennierna i det svenska samhället, exempelvis i skolväsendet och barnhälsovården. ${ }^{17}$ Det är emellertid viktigt att även här understryka att de olika förståelser och teoretiseringar av barns utveckling och hälsa som framhölls i sådana kontexter förändrades över tid genom exempelvis artikulerandet av nya problemkategorier och 
användandet av nya psykologiska instrument. Vidare förekom det signifikanta skillnader beroende på det institutionella sammanhanget. I till exempel skolan ledde den psykologiska och psykiatriska expertisen till en betoning på mätande och testning. Den statligt organiserade barnpsykiatrin, som under 1950- och r 960 -talen befann sig i fas av intensiv expansion, kom i stället att karakteriseras av starkt psykodynamiskt influerade terapiformer med det individuella barnets inre liv i fokus. ${ }^{18}$

Den svenska barnpsykologins och -psykiatrins historia under första halvan av I90o-talet har varit föremål för ett antal studier som sammantaget skisserar bakgrunden till den tidsperiod som står i fokus i denna artikel och påvisar hur barnpsykologisk och -psykiatrisk expertis varit betydelsefull, om än på olika sätt beroende på tidsperiod och plats, för hur svenska barns och ungas hälsa och utveckling diskuterats, teoretiserats och hanterats. Litteraturen är dock desto mer begränsad när det gäller studier av såväl den senare delen av århundradet som icke-institutionella sammanhang.

Den svenska barnpsykologins och -psykiatrins mediehistoria är därför ännu relativt outforskad. ${ }^{19}$ Dock finns det två studier som i detta sammanhang är värda att närmare diskutera då de på skilda sätt fokuserar på mediediskussioner om barns och ungas psykiska ohälsa. Den första är sociologen Mats Börjessons undersökning av den intensiva publiceringen runt slutet av 1990-talet av artiklar som diskuterade neuropsykiatriska diagnoser. ${ }^{20}$ Börjesson tar avstamp i kunskapssociologiska perspektiv och forskning om retorik för att kritiskt analysera hur flera sammanfallande förhållanden understödde denna "kampanj", däribland att neurorelaterade diagnoser och problembeskrivningar började allmänt bli vedertagna i samhället, att den inföll samtidigt som en intensiv debatt om skolan, experternas egenintresse av att föra fram sin syn på barns problem samt dagspressens finansiella intresse av att skriva om känslomässigt laddade berättelser.

Den andra studien är folkhälsovetarna Linda Beckmans och Curt Hagquists kartläggning av bilden av barns och ungas psykiska ohälsa i media, politik och forskning under åren 1988-2008, med det övergripande syftet att granska huruvida de olika aktörerna gav en samstämmig bild. ${ }^{2 r}$ Författarna menar att det fanns en relativt god överensstämmelse mellan myndigheter, media och forskning i hur barns och ungas psykiska hälsa framställdes och att de två förstnämnda ofta återrapporterade forskningen på ett rättvisande sätt.

Vi stödjer oss på dessa två studiers resultat samtidigt som vi vill positionera vår analys i relation till deras frågeställningar och teoretiska ansatser. I jämförelse med vår studie fokuserar Börjesson på ett mer avgränsat problemområde under en viss tidsperiod. Hans studie syftar till att sociologiskt utröna vilka drivkrafter som låg bakom den intensiva debatten kring 
neuropsykiatriska problem. Vi vill i stället hålla oss på "medienivån", utan att i detalj gå in på tänkbara drivkrafter och motivationer, för att mer utförligt kunna fokusera på själva diskussionernas utformning och innehåll och hur dessa förändrats över tid.

Och medan Beckmans och Hagquists val av problemområde och tidsperiod överlappar med vårt vilar deras studie på en, i vår mening, alltför strikt uppdelning mellan media och vetenskaperna, eftersom de vill bedöma huruvida media på ett rättvist sätt återger den "riktiga" forskningen. Vi utgår i stället från att det föreligger en mer komplex relation mellan den mediala arenan och vetenskaperna där de snarare kan sägas utgöra medievetenskapliga nätverk.

Vårt empiriska fokus och analytiska ansats kan därför bidra på flera nivåer till forskning. Genom vår bredare utgångspunkt, både gällande tidsperiod och fokus, kan vår studie ge en mer sammanhållen bild av mediediskussionerna av barns och ungas psykiska ohälsa och belysa såväl kontinuiteter som skillnader över en längre tid. Vår analys vilar även tydligare på ett vetenskapsoch mediehistoriskt ramverk som betonar den intrikata och växelverkande relation som föreligger mellan media och, i vårt fall, de barnpsykologiska och -psykiatriska disciplinerna. En sådan utgångspunkt är, vill vi hävda, värdefull för att ur ett historiskt perspektiv bättre förstå och teoretisera hur mediediskussionerna om barns och ungas psykiska ohälsa vuxit fram.

\section{Material och metod}

För våra syften ansågs Kungliga bibliotekets digitaliserade samling av svenska dagstidningar erbjuda en unik möjlighet att söka genom stora mängder av material, om än med de begränsningar som medföljer när en databas konstruerats av annan part. Samlingen består av alla utgåvor av Aftonbladet, Dagens Industri, Dagens Nyheter, Expressen och Svenska Dagbladet samt även mindre nationella tidningar och lokala tidningar. ${ }^{22}$ Dock är många av de senare digitaliserade i varierande grad. En sökning i databasen innebär därmed att alla de digitaliserade tidningarna söks igenom. En viktig anledning till att analysen huvudsakligen bygger på material från de större nationella tidningarna är att det var i de tidningarna som de alarmistiska diskussionerna om barns och ungas psykiska ohälsa huvudsakligen fördes. Att vissa av tidningarna förekommer så ofta i själva analysen är alltså inte en urvalsfråga utan ett empiriskt resultat. Insamlingsprocessen har inneburit att vi handskats med relativt omfattande mängder material, varför vi valt att i denna artikel fokusera på tidningsmedia och exkludera radio och television, trots att de tänkbart också kunde varit relevanta att studera.

Vi har avgränsat vår analys till att omfatta material från perioden 1968-2008. 
Den svenska barnpsykiatrins framväxt och expansion har, självfallet, skett successivt. Men runt 1968 hade den blivit en etablerad del av den svenska sjukvårdsorganisationen, vilket indikerar att psykisk hälsa och utveckling kommit att bli en grundläggande del i diskussionerna om barns och ungas välmående. Av denna anledning ser vi året som en relevant startpunkt för vår undersökning. Valet att sätta slutåret till 2008 är motiverat av flera skäl. Under 2008 lämnade, som Beckman och Hagquist påpekar, den dåvarande regeringen en proposition till riksdagen som argumenterade för att det var särskilt angeläget med insatser för barn och unga, med särskild hänvisning till den psykiska ohälsan. ${ }^{23}$ Vid denna tidpunkt hade således en uppfattning etablerats om att det förelåg en kris gällande barns och ungas psykiska ohälsa som i sin tur underbyggde politiska insatser och lösningsförslag. Det finns av denna anledning ett värde i att undersöka vilka diskussioner som föregick denna tidpunkt och hur de utformats. Ett annat motiv för valet av 2008 som slutpunkt för undersökningen är av mer praktisk karaktär och handlar om att vi velat hålla mängden material någorlunda hanterbar. Slutligen, att sätta stopp år 2008 motiverades också av KB:s uppsättning av digitaliserade tidningar som börjar ändra form efter 2008, med allt fler digitaliserade lokala upplagor av de nationella tidningarna, vilket skapar många duplikat och försvårar en kvantifiering. Sammantaget ansåg vi därför att det fanns historiska, praktiska och materialmässiga anledningar till att avsluta undersökningen vid 2008. Sammantaget ger undersökningsperioden 1968-2008 möjlighet att både studera upptakten till dagens brännande diskussion och positionera frågan ur ett längre tidsperspektiv.

I syfte att göra en så heltäckande sökning som möjligt utgick vi initialt från en bred uppsättning söktermer, inklusive "barnpsykiatri" och "psykoterapi barn", teoretiska begrepp såsom "objektrelationer" och "beteenderubbningar", samt specifika diagnostiska begrepp som "adhd" och "social fobi". Det blev emellertid tydligt att för att studera de alarmistiska diskussionerna var söktermer såsom "barns psykiska hälsa" och "ungas psykiska hälsa" mest relevanta, varför fördjupande sökningar gjordes kring sådana termer och uttryck. Som ett första steg bedömde vi huruvida varje sökträff var relevant för våra syften. Vi kategoriserade sedan de utvalda artiklarna utifrån publikationsdatum, tidning, artikelrubrik, huruvida det rörde sig om ett "larm" kring barns och ungas psykiska hälsa, om det hänvisades till någon forskning eller expertrapport och om några experter förekom i artikeln (exempelvis intervjuades), vilka begrepp och termer gällande psykisk ohälsa som användes samt om artikeln specifikt nämnde pojkar eller flickor och uppgav något särskilt åldersspann.

Gällande kategoriseringen av "larm" märkte vi att tre kännetecken ofta återkom. De kunde vara uppmanande, antingen i titeln eller i själva arti- 
keln ("Prioritera barns hälsa" eller "Skrota inte syster. Skolbarnen behöver henne mer än någonsin"), använda sig av alarmistiska uttrycksformer och ord ("kris", "oroväckande", "slår larm", "bråkigt redan i första klass") eller hänvisa till en kvantitativ förändring ("var femte pojke psykfall" eller "psykiska ohälsan ökar kraftigt"). I många fall hade artikeln flera av dessa kännetecken, till exempel om den beskrev en oroväckande ökning av självmordsförsök bland unga.

Materialet har analyserats via en innehållsanalytisk, textnära metod med syfte att besvara två övergripande frågeställningar. ${ }^{24}$ För det första ville vi kartlägga förekomsten under undersökningsperioden av mediala larm om barns och ungas psykiska ohälsa. För det andra ville vi analysera innehållet i de alarmistiska artiklarna. Med andra ord var vårt första syfte huvudsakligen att undersöka när alarmistiska artiklar publicerades under tidsperioden medan vårt andra rörde bur artiklarna var utformade och vad de innehöll: Vilka begrepp och termer användes för att beskriva barns och ungas psykiska ohälsa? Vilka aspekter av psykisk ohälsa stod i fokus? Vilka aktörer figurerade?

Teoretiskt uttryckt innebar detta att vi ville spåra "objektet" barns och ungas psykiska ohälsa i artiklarna och analysera hur det artikulerades av experter och professionella, genom vilka former av expertis och terminologier och med stöd i vilka studier och rapporter. Eftersom barnpsykologins och -psykiatrins mediehistoria fortfarande är ett relativt outforskat fält håller sig dock denna studie generellt sett nära empirin, med målet att göra en initial kartläggning och analys av studieområdet.

I analysen visar vi att det regelbundet har publicerats larmartiklar om barns och ungas psykiska ohälsa ända sedan början av undersökningsperioden. Det vill säga att de mediala larmen är i sig inget nytt fenomen, även om dessa kommit tätare och oftare under de senare åren. Det förekommer emellertid ett par episoder där det skedde en intensiv publikation av artiklar som ofta hade ett liknande fokus eller som inbegrep samma aktörer. I det andra steget fördjupar vi oss därför $i$ dessa episoder för att tydligt belysa både kontinuiteter och förändringar i hur barns och ungas psykiska ohälsa artikulerats, exempelvis i vilka begrepp och termer som använts. För tydlighets skull vill vi påminna om att betoningen här ligger på att analysera vilka rapporter och studier som hänvisats och använts för att artikulera och underbygga påståenden om barns och ungas psykiska ohälsa, inte rapporternas innehåll i sig självt. Avslutningsvis tar vi upp några av de, få, motröster som förekommit under åren för att visa på att anspråk om en historisk försämring av svenska barns och ungas psykiska hälsa inte varit helt obestridda. 


\section{Återkommande larm}

Som nämnts framställs ofta rapporterna om barns och ungas psykiska ohälsa, liksom oron över denna, som ett relativt nytt fenomen. I genomgången av vårt material blev det dock tydligt att så inte var fallet. Tvärtom förekom alarmistiska artiklar hela undersökningsperioden igenom, om än med en över tid ökande frekvens.

Figur I. Antal artiklar som kategoriserats som larm under undersökningsperioden. ${ }^{25}$

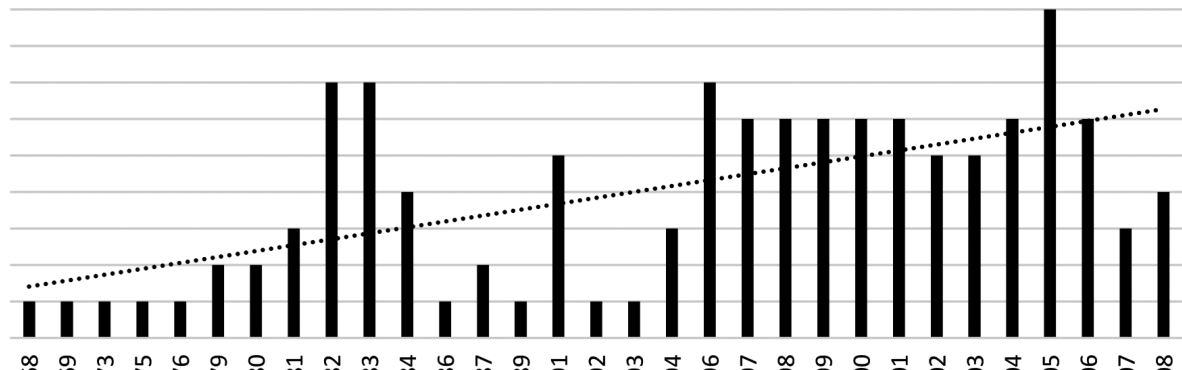

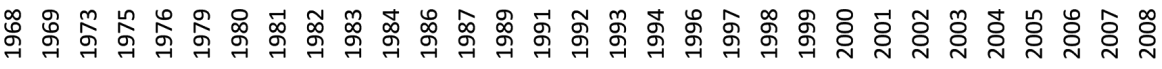

Under exempelvis I969 tog läkaren Rutger Lagercrantz upp att var tredje eller fjärde fyraåring hade kroppsliga eller psykiska symtom som krävde utredning eller behandling ${ }^{26}$ medan en artikel från 1976 hänvisade till SIA-utredningen (Skolans inre arbete) som visade på att "en femtedel av barnen har någon form av mental störning" och det varnades för att "antalet barn med mentalhygienska problem är stort". ${ }^{27}$ Liknande kvantitativa uppskattningar av antalet drabbade barn och unga återkom gång på gång under de följande tre decennierna, och det är värt att citera ett urval av dessa för att visa på hur utbrett dessa faktiskt var. Under det tidiga 1980-talet påstod barnhälsovårdsläkaren och docenten Claes Sundelin att 5-Io procent av alla barn i förskolan hade "allvarliga psykiska störningar" ${ }^{28}$ och Marianne Cederblad, professor i barn- och ungdomspsykiatri, fann att "vart femte barn har psykiska störningar". ${ }^{29}$ I slutet av 1980-talet presenterade Aftonbladet siffror från Västkuststudien som visade att 15 procent av de unga haft självmordstankar, I3 procent hade känt sig deprimerade, Io procent varit nervösa och knappt io procent svårt att sova..$^{30}$

Detta fortsatte under 1990-talet. Till exempel rapporterade Aftonbladet, med hänvisning till professor Anne-Liis von Knorrings studie om "ungdomars själsliga hälsa", att fyra i varje klass var deprimerade ${ }^{3 \mathrm{I}}$ och Svenska Dagbladet återgav att barnpsykiatriutredningens delbetänkande uppskattat att"mellan vart tionde och vart femte barn [har] psykiska problem". ${ }^{22}$ Under 


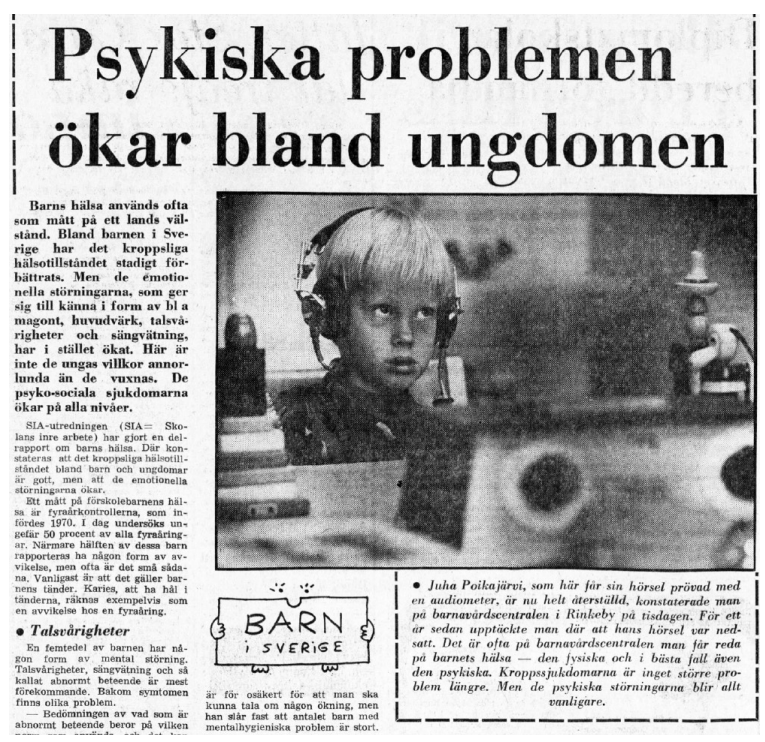

I en artikel publicerad i Dagens Nyheter den I september 1976 refererades en utredning som fann att en femtedel av alla barn hade "någon form av mental störning".

den senare delen av 1990-talet påpekades det särskilt att antalet sökande till barnpsykiatrin ökat kraftigt, exempelvis hade besöken till Stockholms läns barnpsykiatriska mottagningar ökat med 62 procent mellan I99I och $1994{ }^{33}$ men också att själva problematiken förvärrats. Det var med andra ord inte bara fler som sökte, de hade dessutom en tyngre problembild.

Även vid slutet av undersökningsperioden ramade artiklar likaså in "problemet" med barns och ungas psykiska ohälsa genom liknande kvantitativa uppskattningar, som när barnombudsmannen Lena Nyberg redogjorde för hur mellan Io och $\mathrm{I}_{5}$ procent av alla barn sökte psykiatrisk hjälp någon gång under uppväxten, försäljningen av antidepressiva läkemedel till unga i de senare tonåren hade fördubblats sedan 1999 och en tredjedel av alla mellan tio och sjutton år hade sömnsvårigheter. ${ }^{34}$

Det som var nytt under dessa senare år var att flera artiklar inte endast diskuterade kvantitativa uppskattningar av barns och ungas hälsotillstånd utan också innehöll hänvisningar och jämförelser med tidigare decenniers siffror. Medan de alarmistiska artiklarna under I980-talet exempelvis diskuterade hur vart femte barn var psykiskt stört och de från I99o-talet lyfte att problemen verkade tillta i omfattning använde artiklarna från 2000-talet den äldre statistiken för att skarpare argumentera för att det skett en förändring över tid i barns och ungas psykiska hälsotillstånd. Detta kan illustreras av folkhälsoforskaren Sven Brembergs debattartikel 
från 2006 där han gjorde jämförelser med SCB:s undersökningar från slutet av 1980-talet för att hävda att "andelen ungdomar som har psykiska besvär har fördubblats eller tredubblats" ${ }^{35}$ Då hade 9 procent av alla unga kvinnor ängslan, oro eller ångest, nu rörde det sig om 30 procent. Under dessa senare år handlade diskussionerna med andra ord inte bara om att slå fast att svenska barn och unga mådde dåligt utan att med stöd av statistik också påvisa att de mådde sämre än förr.

Vi har i detta första steg av analysen velat lyfta fram två huvudpunkter. För det första att artiklar med alarmistiskt budskap har cirkulerat i svensk dagspress sedan, åtminstone, sent 1960-tal. Barns och ungas psykiska ohälsa har således återkommande presenterats av experter och professionella i alarmistiska och oroväckande termer. Likaså har artiklarna, oavsett decennium, frekvent angivit snarlika uppskattningar av andelen barn och unga som mått psykiskt dåligt. För det andra har vi påvisat att statistisk diskurs om expertis varit centralt i produktionen och cirkulationen av en alarmistisk version av barns och ungas psykiska ohälsa. Denna har särskilt åstadkommits genom kvantitativa uppskattningar av andelen barn och unga som uppfattats lida av psykiska åkommor vid en specifik tidpunkt. Men vissa av de senare artiklarna adderade en dimension genom att kontrastera de äldre uppskattningarna mot samtida statistik. Detta gjorde det möjligt att i vissa fall hävda att det fanns siffror som visade att barns och ungas mående över tid även kommit att försämras och, på så sätt, ytterligare understryka det skriande behovet av insatser. ${ }^{36}$

För att etablera något som såväl sant som verkligt är det, som sociologen Steven C. Ward visat, nödvändigt att olika aktörer vidmakthåller och förlänger sådana anspråk, uppfattningar och praktiker. ${ }^{37}$ Vår analys visar att under åren 1968-2008 kom svensk dagspress med experter och professionella att samproducera en alarmistisk diskurs om svenska barns och ungas psykiska ohälsa som kontinuerligt cirkulerade i den mediala arenan. Detta bidrog till att etablera ett medievetenskapligt nätverk som därtill hade möjlighet att tilltala och enrollera läsare på bred front..$^{8}$

\section{Skiftande fokus, begrepp och aktörer}

Alarmistiska artiklar om barns och ungas psykiska hälsa har således kontinuerligt publicerats genom åren. Men som nämndes ovan förekom det emellertid ett par episoder med en intensiv publikation av artiklar som på ett snarlikt vis diskuterade den psykiska ohälsan. Dessa inbegrep ofta även betydelsefulla förändringar i själva innehållet och utformningen av diskussionerna. Vi vill illustrera dessa genom att analysera fyra episoder omfattande åren 1982-I984, 1996-I997, 200I-2003 samt 2005-2007. Dessa 
var självfallet inte helt fristående då de både föregicks och efterföljdes av andra alarmistiska artiklar. Under dessa år förekom det dock ofta en mer sammanhållen diskussion och exempelvis kunde artiklar i olika tidningar hänvisa till samma rapporter. Det är också i vissa fall fråga om en tätare publikation än annars.

Förutom att episoderna kan belysa kontinuiteter och förändringar i diskussionerna så representerar de var för sig intressanta tidpunkter i mediediskussioner. Under episoden 1982-I984 skedde det en mycket intensivare publikation på ämnet än under såväl de föregående som efterföljande åren och flera aktörer lyfte fram att barns och ungas psykiska hälsa "äntligen" börjat kartläggas genom omfattande statistiska studier. Dessa artiklar, och de undersökningar och rapporter de hänvisade till, öppnade således för den kommande, kvantitativt inriktade, debatten. Episoden under 1996-1997 följdes däremot av en ganska jämn och, i jämförelse med r980-talet, hög frekvens av alarmistiska artiklar. Detta gör den intressant att fördjupa sig $\mathrm{i}$ eftersom den signalerar starten på en tilltagande mediediskussion om barns och ungas psykiska hälsa. De två episoderna under 20oo-talet överlappar delvis varandra gällande innehåll men det finns vissa aspekter som ändå motiverar en uppdelad presentation av dem. Den tredje episoden, som är förlagd till åren 200I-2003, visar dels att barns och ungas psykiska ohälsa började ramas in som ett folkhälsoproblem, vilket medförde att frågan antog allt större och alarmistiska proportioner, dels att det började ske en diversifiering av de involverade aktörerna. Detta konkretiserades ytterligare under den efterföljande episoden, omfattande åren 2005-2007, och diskussionerna präglades då $\mathrm{i}$ ännu större utsträckning av inlägg från organisationer såsom Bris. Under dessa år skedde också den mest intensiva publiceringen kring barns och ungas psykiska ohälsa.

\section{2-1984: De första stora undersökningarna}

Under åren 1982-I984 målade artiklar upp en oroväckande bild av svenska barns och ungas psykiska hälsoläge genom rubriker såsom "Var tionde pojke psykfall" ${ }^{39}$ och "Vart fjärde barn lever med ångest". ${ }^{\circ 0}$ I artiklarna underströks hur illa ställt det egentligen var, som när Aftonbladet redogjorde för att "många tioåringar mår psykiskt illa" och "oroväckande många har tydliga störningar". ${ }^{41}$ Skildringarna av barns och ungas hälsoläge underbyggdes ofta under dessa år med hänvisningar till tre specifika studier: en hälsoundersökning i Stockholm av barn som börjat skolan; Marianne Cederblads studie av 400 barn i Östergötland samt Claes Sundelins, Tore Mellbins och Jean-Claude Vuilles sammanställning av över 5 ooo svenska barns hälsa.

Särskilt var Marianne Cederblad och Claes Sundelin framträdande genom 
att i olika intervjuer framhålla svenska barns och ungas dåliga mående. Exempelvis tog Svenska Dagbladet upp, i en artikel som annars verkade vilja avdramatisera de alarmistiska rapporterna, att trots att det enligt Sundelin på grund av en avsaknad av forskning inte gick att avgöra om svenska barn mådde sämre så hade det $\mathrm{i}$ alla fall påvisats att "ungefär vart tjugonde barn har så stora psykiska problem att de behöver direkt hjälp". Men, menade Sundelin, om även föräldrars och skolpersonalens bedömningar togs i beaktande kom man upp i att" 25 procent av barnen har psykiska problem". ${ }^{2}$

I många av artiklarna användes just psykiska problem eller psykiskt störd för att allmänt beskriva barns och ungas psykiska ohälsa. Men utöver dessa två begrepp cirkulerade också ofta mer avgränsade termer som betecknade specifika problem. Till exempel figurerade psykosomatiska problem, ångest, aggressivitet, koncentrationssvårigheter och ängslighet frekvent $\mathrm{i}$ beskrivningarna. I ett par artiklar framhävdes det vidare att pojkar mådde sämre än flickor, vilket bland annat belades med siffror från rapporten av Sundelin med kolleger som fann att is procent av alla pojkar hade allvarliga psykiska problem, i jämförelse med "bara" 4 procent av flickorna. ${ }^{43}$

I början av 1980-talet pågick det således en diskussion om hur det egentligen var ställt med svenska barns och ungas mentala mående. Det betonades återkommande att det var tack vare de stora studier som nu börjat genomföras - exempelvis av Marianne Cederblad som sades ha gjort"den första stora svenska undersökningen om barns psykiska hälsa"4+ - som häl-
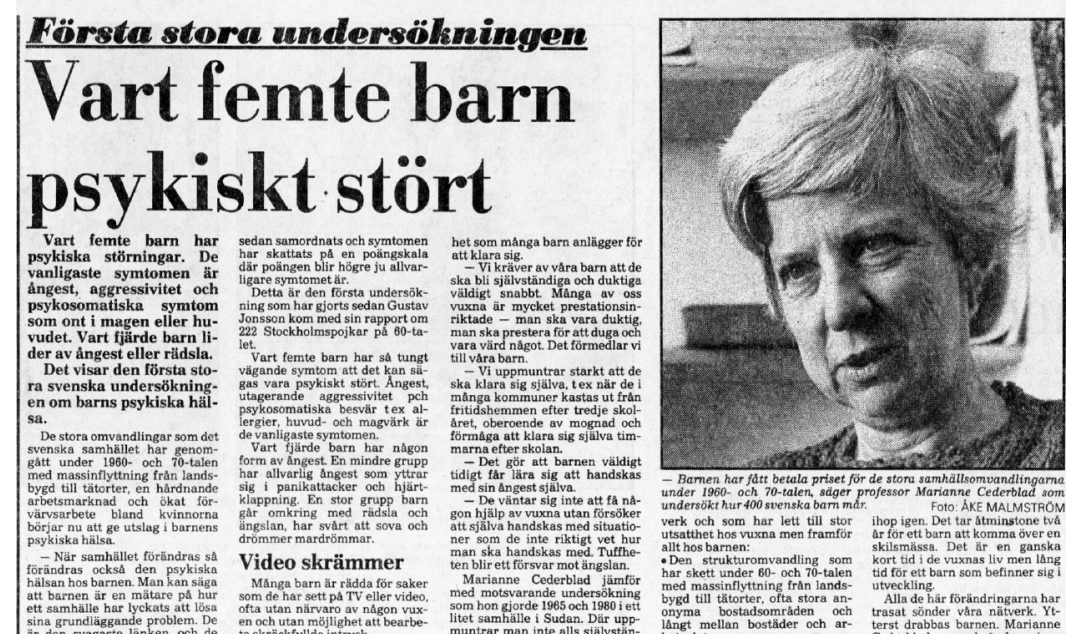

Marianne Cederblad, professor i barn- och ungdomspsykiatri, lyfts fram i en artikel i Dagens Nyheter den 4 november 1984 som den första som genomfört en omfattande undersökning av svenska barns psykiska hälsa. 
soläget bland barn och unga äntligen blivit kartlagt. Dock, menade ofta de ansvariga forskarna, indikerade studierna att läget var högst oroväckande.

\section{6-1997: En mer utbredd och fördjupad ohälsa}

Under de följande åren togs det bland annat upp hur arbetslöshet påverkade ungas mående, ${ }^{45}$ och att ett skikt av"fjärde världens barn", med svåra sociala och psykiska problem, höll på att växa fram i de svenska förorterna. ${ }^{46}$ Men under 1996-I997 går det att urskilja en diskussion som fokuserade på dels det högre söktrycket till barnpsykiatrin, dels att den psykiska ohälsan verkade öka i både omfattning och svårighet. Båda aspekterna berördes exempelvis i Svenska Dagbladets artikel "Psykiatrisk vård av unga ökar starkt" där det påpekades att det inte bara handlade om en ren procentuell ökning av antalet sökande utan också att "patienterna kommer med allt svårare problem". ${ }^{47}$

Liknande påståenden återkom regelbundet, bland annat skrev Barnombudsmannen Louise Sylwander att "allt fler drabbas av psykisk ohälsa"48 och Bodil Långberg från Bris konstaterade att "problemen fortsätter att följa barnen upp i åldrarna och [...] de svårare ärendena [...] blir alltfler och tyngre". ${ }^{49}$ För att underbygga dylika anspråk refererades rapporter och undersökningar från olika instanser och myndigheter, men till skillnad från I982-I984 stod nu färre enskilda forskare i centrum. I stället lyftes statliga organisationer och myndigheter fram som framställare av många av rapporterna, exempelvis Ungdomsstyrelsen och Folkhälsoinstitutets rapport från 1996 samt barnpsykiatriutredningens delbetänkande från 1997. Även uppgifter från PBU-chefer (Psykisk barn- och ungdomsvård) och skolpersonal återgavs i artiklarna.

Likt episoden i början av 1980-talet var begreppet "psykiska problem" centralt i diskussionerna men nu började även termen "psykisk ohälsa" bli allt vanligare. Däremot försvann i princip "störning"/"störd". Störningsbegreppet, som hade en central plats inom den svenska barnpsykiatrin under 1980-talet, betonade med stöd i psykodynamisk teori hur svåra barndomsupplevelser och dåliga föräldrarelationer kunde leda till en "störd" utveckling hos individen..$^{\circ}$ Ohälsa, å andra sidan, verkade i detta sammanhang stå för en mindre binär uppdelning mellan hälsa (normal) och sjukdom (störd) och inte till lika stor utsträckning hänga samman med individens utveckling. I stället betonade ohälsobegreppet det sociala sammanhangets betydelse för barns och ungas mående. Samtidigt som barns och ungas psykiska ohälsa ansågs öka började således ohälsan artikuleras på ett nytt vis där den allt mer försköts till att vara ett, förhoppningsvis tillfälligt, tillstånd, inte en utvecklingsrelaterad störning.

Förskjutningen i övergripande terminologi medförde emellertid inte 
några drastiska förändringar gällande de specifika termer som cirkulerade. De som ofta användes, och som delvis överlappade med terminologin från I980-talet, var exempelvis "depression", "ångest", "anorexi", "stress", "huvudvärk" och "koncentrationssvårigheter". Dock började framställningen av pojkars respektive flickors ohälsa ändras då det nu, i kontrast till tidigare, var flickor som återkommande påstods må sämst. Exempelvis återgav en Aftonbladet-artikel siffror från Ungdomsstyrelsens och Folkhälsoinstitutets rapport som visade att tjejer oftare led av ont i huvudet, magont och koncentrationssvårigheter. ${ }^{\text {II }}$ Även Beckman och Hagquist påpekar att flickors "oroväckande" nivåer av psykiska ohälsa genomgående lyfts fram i media men genom att inkludera material från 1970- och det tidiga I980-talet kan vi således se att denna emfas verkar slå igenom först under den senare hälften av undersökningsperioden..$^{2}$

\section{I-2003: Ett akut folkhälsoproblem}

Även under åren 200I-2003 uttryckte tidningsartiklar i många fall en stark oro över svenska barns och ungas psykiska mående, som verkade bli allt sämre. En ledare från 200I i Dagens Nyheter menade att "den ökande psykiska ohälsan bland barn är alarmerande", med ett fördubblat antal hjälpsökande till barn- och ungdomspsykiatrin, svårare problematik och allt yngre barn..$^{53} \mathrm{I}$ andra tidningar lyftes liknande budskap fram och läget sades ha förvärrats bara under de senaste åren. Exempelvis skrev Svenska Dagbladet att "jämfört med för fem år sedan är det psykiska lidandet i dag tyngre och problemen svårare att komma till rätta med" ${ }^{4}$ och i Aftonbladet gick det att läsa att "svenska skolbarn mår i dag mycket sämre psykiskt jämfört med för tio år sedan".55

Utöver den uppfattade försämringen av barns och ungas psykiska hälsa går det att urskilja en förändring i inramningen av frågan. I Svenska Dagbladet formulerades det som att" den psykiska ohälsan [...] har blivit ett nationellt problem ${ }^{96}$ och i en intervju beskrev en Bup-chef den psykiska ohälsan som "det i särklass största folkhälsoproblemet bland barn och ungdomar". ${ }^{57}$ Uttalanden om att svenska barn och unga mådde dåligt psykiskt var, som påpekats, något som återkom under åren. Det som var nytt under denna episod var att barns och ungas psykiska ohälsa allt tydligare artikulerades som ett akut folkhälsoproblem, vilket ytterligare bidrog till att diskussionerna distanserade sig från det fokus på individens "störning" som präglade åren I982-1984..$^{88} \mathrm{I}$ stället blev det till en fråga som berörde - eller åtminstone borde beröra - alla i Sverige.

Argumentationen stödde sig på rapporter och undersökningar såsom Socialstyrelsens folkhälsorapport, ULF-undersökningen (Undersökningen 
av LevnadsFörhållanden), Barnombudsmannens rapport "Elevhälsa" samt information om söktryck och problembild från barnpsykiatriska verksamhetschefer. Mångfalden av rapporter och undersökningar hade sin motsvarighet i mängden aktörer som figurerade i diskussionerna. Det går att påträffa Barnombudsmannen, SCB, Rädda Barnen, forskare som professorn i barnpsykiatri Anne-Liis von Knorring och professionella såsom överläkare Barbro Thurfjell samt representanter från olika förbund, däribland Psykologförbundet och Vårdförbundet. Detta ger vid handen en breddad uppsättning aktörer, med såväl statliga myndigheter som enskilda individer, civilsamhälleliga organisationer och facksammanslutningar. Men fastän fler aktörer var inblandade förde de alla fram en enstämmig - och alarmistisk - version av barns och ungas psykiska hälsa.

Begreppsmässigt kretsade diskussionerna framförallt kring "(o)hälsa" i olika former, exempelvis den "psykiska ohälsan"\$9 eller barn och ungas "psykosociala hälsa". ${ }^{60}$ Mer specifika ohälsobegrepp som cirkulerade var "hyperaktivitet" och "utåtagerande", "huvudvärk", "magont", "ångest", "oro", "depressioner", "ätstörningar", "självmord" och "sömnsvårigheter". Det handlade således om en bred palett av psykologiska och psykiatriska termer. Medan till exempel ångest och sömnsvårigheter förekommit tidigare dök ett par ganska omskrivna nytillskott upp under dessa år, såsom "självdestruktivitet". Med avseende på dessa var det särskilt flickors mående som togs upp, till exempel påstods fler flickor vara deprimerade och ha självskadebeteende såsom att skära sig i armarna.

Under 2000-talet kan flertalet dramatiska rubriker återses i medierapporteringen. Ett exempel är en längre artikel i Dagens Industri från den 30 september 2005 där ångest framställs som "de ungas nya arvedel".

Men även psykosomatiska problem som huvudvärk och magont sades vara mer framträdande i denna grupp.

\section{5-2007: En fråga som berör allt fler}

Till skillnad från tidigare präglades diskussionerna under åren 2005-2007 av jämförelsevis många debattinlägg, ofta med starkt alarmistiska rubriker såsom "Nödropen om självmord ökar från unga flickor" och "Psykiska 
ohälsan förvärras mycket bland svenska barn” ${ }^{6 r}$ Men även övriga artiklar utmärktes av oroväckande rubriceringar. Bland annat publicerade Dagens Industri en artikel rubricerad "Ångest är de ungas nya arvedel" ${ }^{\text {"62 }}$ och Svenska Dagbladet summerade ungas hälsoläge under rubriken "Unga mår sämre än sina föräldrar. Fyra gånger fler försöker begå självmord - dubbelt så många är feta". ${ }^{{ }_{3}}$ Sven Bremberg målade upp en liknande bild i ett debattinlägg där han påstod att andelen unga med psykiska besvär hade "fördubblats eller tredubblats" sedan slutet på i980-talet. ${ }^{64}$

Att situationen var ohållbar framhölls av många olika aktörer, däribland Bris, Barnombudsmannen, Psykologförbundet, enskilda läkare och Socialstyrelsen. Många uttalade sig likt den representant från Lärarnas

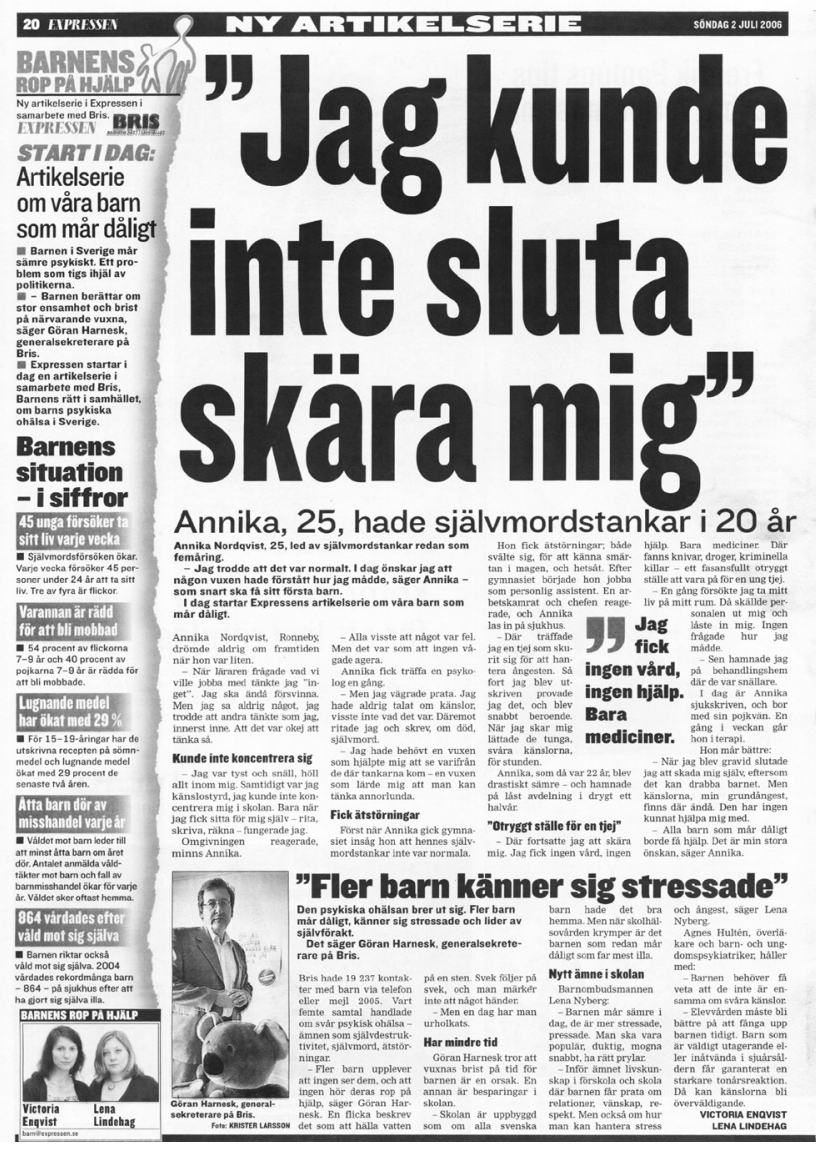

Under 2000-talet blir allt fler aktörer involverade i den offentliga diskussionen om barns och ungas psykiska ohälsa. Den 2 juli 2006 publicerar exempelvis Expressen i samarbete med Bris en artikelserie om barns och ungas uppfattade försämrade mående. 
Riksförbund som påstod att det var "sedan länge känt att den psykiska ohälsan breder ut sig bland barn och ungdomar". ${ }^{65}$ Av alla aktörerna var de två förstnämnda - Bris och $\mathrm{BO}$ - synnerligen aktiva i debatten. De stod bakom flera debattinlägg var och exempelvis samarbetade Bris med Expressen i utformandet av en artikelserie om "våra barn som mår dåligt". ${ }^{66}$

Förskjutningen mot en bredare uppsättning aktörer kunde urskiljas redan under 200I-2003 men denna intensifierades under 2005-2007, bland annat genom att civilsamhälleliga organisationer började inta en allt mer central plats i det medievetenskapliga nätverket. Detta fick även avtryck i vilka rapporter och undersökningar som hänvisades. Medan det förekom återgivanden av Socialstyrelsens folkhälsorapport och siffror från bland annat SCB så syntes både Barnombudsmannens rapport "Satsa tidigt" och Bris årsrapport flitigt i diskussionerna.

I likhet med föregående episod ledde dock inte breddningen av aktörer till några större omvälvningar i de centrala termerna och begreppen. "Psykisk ohälsa" utgjorde fortfarande det primära begreppet för att mer allmänt beskriva barns och ungas psykiska välmående och även de specifika termerna var ganska stabila. De som ofta förekom var exempelvis "oro", "självmord", "ont i huvudet" och "ont i magen", "psykosomatiska symtom", "depression", "stress", "självdestruktivitet" och "ångest". Likaså var det återigen tjejer som lyftes fram i diskussionerna som mest i riskzonen för att erfara sådana problem.

\section{Övergripande kontinuiteter och förändringar}

För att summera framhölls det genomgående över åren att svenska barn och unga mådde dåligt psykiskt. Sättet som ohälsan artikulerades förändrades dock under undersökningsperioden. I början av i980-talet användes mest "psykisk störning" eller "psykiska problem" som den övergripande termen medan det under 1990-talet och framåt skedde en förskjutning till att huvudsakligen prata om barns och ungas "psykiska ohälsa". Under 2000talet presenterades även frågan ofta som ett nationellt folkhälsoproblem. Den uppsättning specifika begrepp och kategoriseringar som användes för att diskutera avgränsade aspekter av barns och ungas psykiska mående var dock mer stabil undersökningsperioden igenom. Exempelvis förekom "koncentrationssvårigheter", "ångest" och olika "psykosomatiska symtom" under i princip alla fyra decennier. Likväl tillkom några och andra föll bort. "Aggressivitet" användes till exempel relativt ofta när barn och ungas psykiska problem beskrevs under åren 1982-1984 medan det inte alls förekom i samma utsträckning under de senare decennierna. Däremot började exempelvis "självskadebeteende" nämnas allt oftare under tidigt 2000-tal. 
Uppsättningen aktörer blev då också desto rörligare med allt fler aktörer involverade i diskussionerna. Särskilt påtaglig var den ökade närvaron i diskussionerna som aktörer som Barnombudsmannen och Bris hade.

\section{De sporadiska motrösterna}

Medan flera barnpsykologiska och -psykiatriska frågor debatterades intensivt i Sverige under dessa decennier, exempelvis adhd/damp-diagnosen, ${ }^{67}$ förekom intressant nog ingen ifrågasättande debatt kring barns och ungas psykiska ohälsa. Diskussionerna präglades i stället av samstämmighet kring situationen. Icke desto mindre fanns ett fåtal som försökte lansera en annan tolkning av hälsoläget. Vi vill avsluta analysen med att lyfta fram några av de motröster som förekom under undersökningsperioden, för att undvika att ge en alltför enhetlig bild av diskussionerna. Dessa förde emellertid en ganska isolerad tillvaro och deras budskap plockades aldrig riktigt upp av andra aktörer. Det var på så sätt inte tal om en omfattande, sammanhållen gruppering, vilket återspeglar sig i hur lång tid det gick mellan artiklarna.

En tidigt ifrågasättande artikel som publicerades 1984 i Svenska Dagbladet utgick från barnläkaren Bengt Jormings doktorsavhandling. ${ }^{68}$ Genom att undersöka närmare 4000 barn i Eskilstuna sades Jorming ha kommit fram till resultat som "krossar flera myter som kommit att bli 'självklara sanningar"', däribland att västerländska barn var sällsynt friska fysiskt men att de psykosociala problemen ökade. Medan Jorming fann att vart tionde barn hade psykiska eller psykosociala problem - på denna punkt skilde sig, som vi sett, inte Jormings uppskattning från många andra experters - menade han att detta var"siffror som hållit sig konstanta i flera årtionden”. Det som oroade Jorming var därför inte andelen barn med psykiska problem utan den höga frekvensen kroppsliga åkommor.

Docenten och läkaren Bruno Hägglöf framhöll ett liknande budskap i en artikel i Aftonbladet från 2000 med rubriken ”Det var inte bättre förr. Forskare: Dagens barn och ungdomar mår minst lika bra". ${ }^{69} \mathrm{Hägglöf} \mathrm{menade}$ att "många tror att psykiska problem ökat hos barn och ungdomar, så är det inte". Däremot, fortsatte han, sökte fler hjälp, bland annat på grund av nedskärningar i skolan och att det numera var mindre skambelagt att söka hjälp. I sin undersökning av 4 ooo barn i Västerbotten fann Hägglöf att runt 15 procent av högstadieeleverna och mellan 7 och io procent av barnen i lägre åldrar led av måttliga till svåra psykiska problem. Detta skulle dock, enligt Hägglöf, inte ses som något alarmerande utan "så här ser den psykiska sjukligheten ut hos barn oc\$h [sic!] ungdomar".

Både Jorming och Hägglöf argumenterade med utgångspunkt i egna undersökningar av barns och ungas hälsa. I Expressen kritiserade David 
Eberhard, överläkare i psykiatri och författare till boken I trygghetsnarkomanernas land. Sverige och det nationella paniksyndromet (2006), i stället Bris för att ha dragit felaktiga slutsatser i sin årsrapport 2007.7 Förvisso, menade Eberhard, hade Bris haft något fler kontakter under 2007 än året innan men denna "helt marginella ökning har fått ett närmast hysteriskt genomslag i medierna". Snarare än att signalera en faktisk ökning i ohälsa handlade det troligen mera om att Bris var mer välkänt än förut bland barn och unga samt att det var lättare att mejla, vilket allt fler unga gjorde nu, än att ringa. Huruvida svenska barn verkligen mådde sämre gick, enligt Eberhard, inte att svara på eftersom det saknades reella fakta. Avslutningsvis påpekade Eberhard att de barn och unga som mår riktigt dåligt ofta inte orkar höra

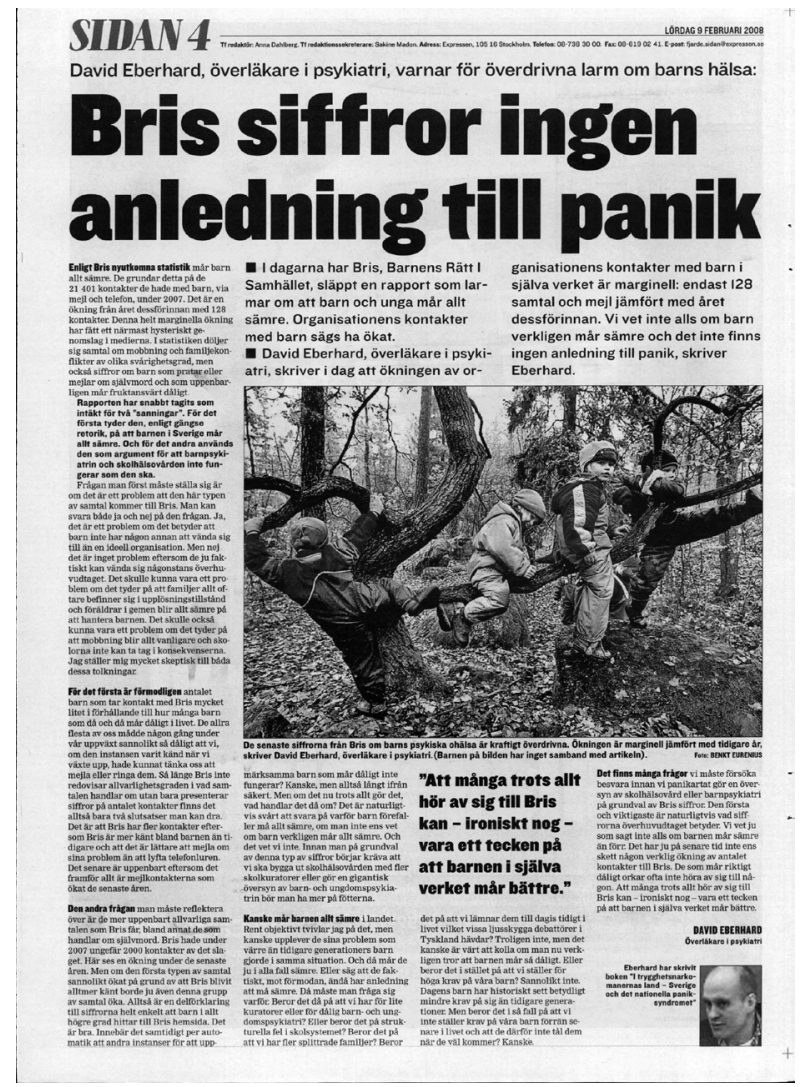

Under decennierna fanns det även de som kritiserade och ifrågasatte bilden av barns och ungas psykiska ohälsa som allt sämre. En av de som deltog i debatten var psykiatern och överläkaren David Eberhard som menade på att det inte finns stöd för att uttala sig om hur barns och unga faktiskt mår. Expressen 9 februari 2008. 
av sig till någon. Det större antalet kontakter till Bris kunde därför "ironiskt nog betyda att barnen i själva verket mår bättre”.

Eberhards resonemang togs även upp på Expressens ledarsida. ${ }^{7 \mathrm{I}}$ Ledaren frågade om det kanske egentligen var "skadligt att generellt utmåla dagens barn och ungdom som djupt deprimerade. Tänk om vi skapar en ond cirkel, där vi ger barnen en deprimerad, sjuk, offeridentitet som de sedan väluppfostrat odlar". Det var således "ett ofog" att skriva "larmrapporter och övertända debattartiklar" som framställde helt normala upplevelser och känslor - som att känna sig deppig under tonåren - som något oroväckande och farligt.

Dessa kritiska inlägg utgjorde en väldigt liten del av de analyserade artiklarna. De är emellertid intressant för de påvisar cirkulationen av en version av barns och ungas psykiska ohälsa som förvisso också vilade på en statistisk inramning av frågan men som inte understödde en alarmistisk ton. Dessa försök var dock inte särskilt framgångsrika i att enrollera och mobilisera allierade och de kritiska rösterna förblev en isolerad minoritet i debatten.

\section{Avslutande diskussion}

Genom att analysera artiklar publicerade i dagspress under åren I968-2008 har vi visat att det perioden igenom förekom alarmistiska artiklar som framhöll att det var illa ställt med svenska barns och ungas psykiska hälsa. Det var även vanligt att artiklarna, oavsett tidsperiod, uppgav liknande uppskattningar av andelen barn och unga som led av psykisk ohälsa, med siffror som pendlade mellan var tjugonde till vart femte barn. Såvitt vi kunnat finna fanns det inte någon tidpunkt under perioden där svenska barns och ungas psykiska hälsa genomgående skildrades i positiva och optimistiska termer. Svårigheterna med att till fullo definiera vad som utgör ett "medielarm" och den omfattande mängd material som svensk dagspress tillhandahåller gör att viss aktsamhet bör iakttas gällande långtgående slutsatser. Icke desto mindre synliggör analysen att det funnits en övergripande kontinuitet under de fyra decennierna i att konstituera barns och ungas psykiska ohälsa som illavarslande och i behov av akuta insatser. Medan det i den samtida offentliga diskussionen ofta framställs som att barns och ungas psykiska ohälsa, och oron över densamme, är ett relativt nytt fenomen så har detta kunnat påvisas ha pågått under en längre tid. Vår studie visar följaktligen på betydelsen av att positionera samtidens diskussioner och oro i ett längre tidsperspektiv.

I artikeln har vi också lyft fram andra viktiga kontinuiteter och förändringar i diskussionerna. För det första har den övergripande terminologin till viss del ändrats under åren. I det tidiga I980-talet var termerna "psykiskt störd" och "psykiska problem" centrala i framskrivningen av barns och 
ungas mentala mående men under 20oo-talet började "psykisk ohälsa" bli den dominerande beteckningen. Under denna senare period övergick även frågan om barns och ungas psykiska ohälsa till att allt tydligare artikuleras som ett nationellt folkhälsoproblem. För det andra fanns det i de specifika ohälsobegreppen, trots förskjutningen från "störning" till "ohälsa", en någorlunda kontinuitet över decennierna. Bland annat förekom "ångest" och "psykosomatiska symptom" genomgående under åren.

Denna kontinuitet blir i synnerhet intressant mot bakgrund av att dessa decennier i övrigt såg relativt stora förändringar i hur barns och ungas utveckling och hälsa teoretiserades av psykologiska och psykiatriska experter. $^{72}$ Exempelvis hade neuropsykologiska och -psykiatriska diagnoser och kategoriseringar inget större genomslag $i$ just denna diskussion om barns och ungas psykiska ohälsa, till skillnad från den mer avgränsade mediedebatt från slutet på 1990-talet som Börjesson undersökt.73

För det tredje breddades uppsättningen aktörer under den undersökta perioden. Under 1970- och 1980-talen var det huvudsakligen forskare som drev frågan, under 1990-talet blev statliga organisationer och myndigheter, såsom Folkhälsoinstitutet, mer framträdande. Diskussionerna under 200o-talet präglades av en ännu mer diversifierad uppsättning aktörer. Barnombudsmannen var allt aktivare, fackliga representanter, såsom ordförandena för Psykologförbundet och Vårdförbundet, skrev debattinlägg och civilsamhälleliga föreningar som Bris intog en central plats i diskussionerna. ${ }^{74}$ Intressant nog resulterade inte detta i flera olika versioner av barns och ungas psykiska ohälsa eftersom i princip alla aktörer höll med varandra, bland annat genom att hänvisa till varandras rapporter, och därmed befäste en enhetlig bild av att barn och unga mådde allt sämre.

En nyckel till att förstå både enigheten bland aktörerna och kontinuiteten i begreppsapparaten tror vi ligger i att frågan om barns och ungas psykiska ohälsa kom att konstitueras i en statistisk och huvudsakligen deskriptiv form. Stundtals framhöll aktörer tänkbara orsaker till den uppfattade försämringen i psykisk hälsa men dessa inbegrep oftast generella samhällsförklaringar, exempelvis en försämrad arbetsmarknad, snarare än utvecklingspsykologi. På så sätt undveks mer teoretiskt färgade resonemang om ohälsans psykologiska orsaker och bakomliggande faktorer.

Detta sätt att definiera frågan framträdde därtill ännu skarpare under tidigt 2000-tal när den transformerades till en folkhälsofråga. Tidigare forskning har visat hur svenska hälsopolitiska rapporter och policydokument på barn- och ungdomsområdet genomgående förespråkat universella insatser, baserade på ett samhälleligt och socialt orienterat tänkande som betonat strukturella, snarare än individuella, orsaker. ${ }^{75}$ Detta tänkande, som sedan 1980-talet kom att formuleras i termer av ett "folkhälsoperspektiv", 
var således centralt även i 2000-talets mediediskussion om barns och ungas psykiska ohälsa, med den skillnaden att det nu fanns en tydligare betoning på individuella uttryck för ohälsa.

Genom denna förskjutning blev problemområdet barns och ungas psykiska ohälsa artikulerat inom ramarna för en, för att tala med vetenskapsfilosofen Ian Hacking, statistisk style of reasoning, där fenomenet antog formerna av ett epidemiologiskt objekt. ${ }^{6}$ Psykisk ohälsa blev något som primärt greppades på en deskriptiv beteendenivå - hur ofta har man huvudvärk? har man svårt att sova? - och vars statistiska fördelning i befolkningsgruppen barn och unga kunde beräknas, sammanställas och cirkulera i dagspressen. Detta kan tänkas - åtminstone delvis - ha distanserat frågan om barns och ungas psykiska ohälsa från den turbulenta historia som annars präglat debatterna om etiologi och teori inom barnpsykologi och -psykiatri. I stället öppnade detta för olika aktörer att mötas kring en kvantitativ inramning av frågan, vilket, som historikern Ted Porter påvisat, ofta medför att framställningen uppfattas som mer neutral och objektiv.77

Denna samsyn kunde till och med återfinnas bland de forskare och professionella som (utan framgång) försökte lansera en icke-alarmistisk version av barns och ungas psykiska ohälsa. Trots att de inte höll med om de tolkningar och slutsatser som andra gjorde inbegrep deras kritik inte några egentliga försök att konstituera problemområdet genom andra vetenskapliga praktiker, såsom experimentella studier i laboratoriemiljöer..$^{78}$ Följden blev att frågan om barns och ungas psykiska ohälsa dominerades av aktörer som utgick från en statistisk och folkhälsoinriktad inramning, i stället för exempelvis kliniker eller utvecklingspsykologiska forskare. Vår analys bidrar till en fördjupad förståelse av hur problemområdet konstituerats i diskussionerna och dess implikationer för både kontinuiteten i begreppsrepertoaren och den samsyn som har karakteriserat diskussionerna.

Utöver dessa epistemologiska dimensioner har, som nämndes inledningsvis, forskare visat hur psykologin och psykiatrin påverkat hur människors förstår och agerar på sig själva som subjekt.79 Såväl artikulerandet av barns och ungas psykiska mående i statistiska termer som förskjutningen mot att utgå från "psykisk ohälsa", och inte "störning", som den centrala termen, ledde i vår mening till en tydlig normalisering av psykisk ohälsa. Återkommande genom decennierna presenterades siffror som visade att en "oroväckande" andel barn och unga led av psykisk ohälsa. Utöver den alarmistiska tonen signalerade detta att sådana problem redan var relativt vanligt förekommande och att det därför inte var något "konstigt" eller exceptionellt om man själv, eller någon man kände, brottades med liknande svårigheter.

Vidare betonade ohälsobegreppet att det inte handlade om en binär uppdelning mellan att antingen ha eller inte ha psykisk ohälsa; det var i 
stället fråga om en skala där det fanns grader av (mer eller mindre tillfällig) ohälsa. Detta begrepp var därtill betydelsemässigt så pass öppet att det kunde inkludera kvalitativt vitt skilda upplevelser, från att känna oro inför en pressad skolsituation till att uppleva en så djup depression och meningslöshet att man får tankar på att ta sitt liv.

Problematiseringen av området erbjöd i sin tur presumtiva läsare olika möjligheter att ta positioner i detta medievetenskapliga nätverk. ${ }^{80}$ Som ett exempel framhävde den statistiska formen tillsammans med den alarmistiska inramningen att en betydande andel av alla barn och unga redan lider av ohälsa och att desto fler någon gång riskerar att uppleva liknande problem. Den deskriptiva karakteriseringen möjliggjorde för läsare att själva identifiera och kategorisera sin ohälsa. Det handlade om att känna igen om man hade ont i huvudet, svårt att sova, eller kände sig ängslig. I kontrast till exempelvis den psykodynamiska uppfattningen, där psykologiska problem delvis är omedvetna, var det således inte nödvändigt med barnterapeutisk expertis för att identifiera psykisk ohälsa. ${ }^{8 \mathrm{I}} \mathrm{I}$ detta medievetenskapliga nätverk cirkulerade på så sätt inte "endast" kvantifierade representationer av gruppen barns och ungas hälsotillstånd, det cirkulerade likaså möjliga sätt för individer - barn och unga men även exempelvis föräldrar - att begripliggöra och agera på sitt eget och andras psykiska mående..$^{82}$

Som James A. Secord påpekat är en central fråga hur kunskap "cease to be the exclusive property of a single individual or group and become part of the taken-for-granted understanding of much wider groups of people". ${ }^{8}$ Vår förhoppning är att vi, genom att lyfta fram såväl historiska kontinuiteter som förändringar i hur svenska barns och ungas psykiska hälsa har artikulerats av experter i svensk media under åren 1968-2008, visat på hur en kvantifierad, alarmistisk version av barns och ungas psykiska ohälsa cirkulerat under fyra decennier i svensk dagspress och, på så sätt, haft möjlighet att etablera sig som en gemensam utgångspunkt för experter, politiker, föräldrar och barn och unga. Genom detta har vi velat avdramatisera de samtida diskussionerna i denna fråga, visa på förändringar i utformningen av diskussionerna samt lyfta fram tänkbara konsekvenserna som just detta sätt att konstituera problemområdet kan ha haft för allmänheten.

Det är viktigt att påpeka att vårt mål inte varit att besvara frågan om ohälsan ökat eller inte. Däremot har vi velat belysa både att uttrycken och termerna för ohälsa delvis förändrats och att diskussionerna om och oron över barns och ungas psykiska ohälsa varit tätt sammanbunden med vissa mediala arenor och de möjligheter de erbjudit för en bred cirkulation av expertis. Så länge frågan i det närmaste enbart kretsar kring om ohälsan ökat eller inte så förbises andra viktiga aspekter, såsom att oron över barns och ungas psykiska ohälsa varit tätt sammankopplad med specifika former 
av barnpsykologisk och -psykiatrisk expertis, vilka kan vara av stor betydelse för att mer mångfasetterat kunna resonera kring barns och ungas psykiska ohälsa i Sverige i dag.

\section{Summary}

In the last decade, poor mental health among children and young people has been a recurrent topic of discussion in Swedish media. These discussions have predominately been characterized by both a dystopic tone and a presentism that, combined, has led to a framing of the situation as worse than ever and in need of immediate solutions. Based on an analysis of articles in Swedish daily newspapers from 1968 to 2008 , we show in this article that alarming articles on the mental health of Swedish children and young people have, in fact, appeared frequently throughout these four decades and that these articles, regardless of year of publication, presented similar statistics over how many children and young people suffered from poor mental health. Alarms and concerns about the poor mental health of children and young people thus have a longer history than what is often claimed by contemporary actors. Nevertheless, we could also discern several important shifts over the years. In the early decades, the discussions revolved around the concepts of psychological disorders and psychological problems, while poor mental health became central during the latter part of the time period. However, more specific psychological and psychiatric terms, such as anxiety and psychosomatic symptoms, were more stable and did not really change to any significant extent over the years. Moreover, the set of actors involved in the discussion expanded and diversified over time, with civil society organizations in particular taking a more prominent place. To conclude, we argue that the consensus and consistency among the actors over time may be due to how the issue was framed in quantitative, descriptive and epidemiological terms, as this avoided any theoretically charged debates over the etiology and categorization of disorders, a question that has otherwise had a quite turbulent history in child psychiatry and psychology and which has divided experts and professionals. The discussions have also offered certain self-understandings to the public, including a normalizing conception of poor mental health presenting such problems as a transient condition that could possibly afflict any child or young person.

Keywords: Child Psychology and Psychiatry, Media, Expertise, Epidemiology, Alarms 


\section{Noter}

I "Psykisk ohälsa" blir, som vi visar i analysen, allmänt vedertaget först under slutet av I990-talet. Vi har dock valt att utgå från detta begrepp eftersom vår utgångspunkt ändå är de samtida diskussionerna om ohälsan. Men vi gör detta med en medvetenhet om att det inte är det enda, eller det givna, sättet att konceptualisera fenomenet.

2 Gustav Fridolin, "Så ska skolan hantera den växande psykiska ohälsan", Dagens Nyheter I6/8 2016.

3 Cecilia Björkelund, Mats Fredriksson, Tord Ivarsson, Lars von Knorring, Johan Lundberg, Lise-Lotte Risö Bergerlind, Ingela Skärsäter, Anders Berg \& Lars-Torsten Larsson, "Unga med psykisk ohälsa måste få hjälp snabbare", Dagens Nyheter I3/12 2 or7.

4 Se t.ex. Karin Johannisson, Melankoliska rum. Om ångest, leda och sårbarhet iförfluten tid och nutid, Stockholm 2010, s. 59-I55; Ian Hacking, "Kinds of people. Moving targets", Proceedings of the British Academy 2007:151, s. 292-304; Nikolas Rose, Governing the Soul. The Shaping of the Private self, London 1999; Annika Berg, De sambällsbesvärliga. Förhandlingar om psykopati och kverulans i 1930- och 40-talens Sverige, Göteborg 2018; Petteri Pietikainen, Neurosis and Modernity. The Age of Nervousness in Sweden, Leiden 2007.

5 Bruno Latour, Pandora's Hope. Essays on the Reality of Science Studies, Cambridge 1999, s. 98-I08; Anders Ekström (red.), Den mediala vetenskapen, Nora 2004; Agustí Nieto-Galan, Science in the Public Sphere. A History of Lay Knowledge and Expertise, London 20I6, särskilt s. I2-I5, I94.

6 James A. Secord, "Knowledge in transit", Isis 2004:95 (3), s. 654-572.

7 Johan Östling, David Larsson Heidenblad, Erling Sandmo, Anna Nilsson Hammar \& Kari H. Nordberg, "The history of knowledge and the circulation of knowledge. An introduction", i Circulation of Knowledge. Explorations in the History of Knowledge, Johan Östling, Erling Sandmo, David Larsson Heidenblad, Anna Nilsson Hammar \& Kari H. Nordberg (red.), Lund 2018, s. I7-23.

8 David Larsson Heidenblad, "From content to circulation. Influential books and the history of knowledge", i Östling, Sandmo, Larsson Heidenblad, Nilsson Hammar \& Nordberg 2018, s.7I.

9 Charles L. Briggs \& Daniel C. Hallin, Making Health Public. How News Coverage is Remaking Media, Medicine, and Contemporary Life, London 2016, s. I2-I3.

Io Angående problemen med populariseringsbegreppet, se t.ex. Stephen Hilgartner, "The dominant view of popularization. Conceptual problems, political uses", Social Studies of Science 1990:20, s. 519-539.

II Andrew Scull, Madness in Civilization. A Cultural History of Insanity, from the Bible to Freud, from the Madhouse to Modern Medicine, Princeton 2015; Wade E. Pickren \& Alexandra Rutherford, A History of Modern Psychology in Context, Hoboken 2oro; Roger Smith, Between Mind and Nature. A History of Psychology, London $20 \mathrm{or}$.

I2 Angående kultursjukdom, se Karin Johannisson, "Om begreppet kultursjukdom", Läkartidningen 2008:44, s. 3129-3132; för ekologiska nischer, se Ian Hacking, Mad Travelers. Reflections on the Reality of Transient Mental Illness, Cambridge 2002.

I3 Maria Björk, Problemet utan namn? Neuroser, stress och kön i Sverige från 1950-1980, Diss., Uppsala universitet 2011 .

I4 Roger Qvarsell, "Från vanart till psykopati. Om barnpsykiatrins framväxt i Sverige under mellankrigstiden", Lychnos 1985, s. 167-189; Roger Qvarsell, Skall jag taga tillvara på min broder? Tolv artiklar om vårdens, omsorgens och det sociala arbetets historia, Umeå 1993, 
s. 83-97; Ulf Jönson, Bråkiga, lösaktiga och nagelbitande barn. Om barn och barnproblem vid en rådgivningsbyrå i Stockholm 1933-1950, Diss., Linköpings universitet, 1997.

I5 Roger Qvarsell, "Mentalhygien och psykisk hälsovård", i Hur skall själen läkas? Den psykiatriska vårdens förändringar, Bengt Erik Eriksson \& Roger Qvarsell (red.), Stockholm I997, s. I29; I43-I44. Se även Karin Zetterqvist Nelson, "'A reason behind every action' - The early years of Swedish child psychiatry 1930-1945", Revue d'bistoire de l'enfance "irrégulière". 20I6:I8, s. 20I-2II.

I6 Åsa Bergenheim, Varm choklad och psykoterapi. Om Ericastiftelsen $i$ Stockholm, Stockholm 2013; Karin Zetterqvist Nelson, "The Sandtray technique for Swedish children I945-I96o. Diagnostics, psychotherapy and processes of individualisation", Paedagogica Historica 20Ir: 47 (6), s. 826.

I7 Anna Larsson, "School psychologists and experts. Some notes on the uses of behavioural science in post-war Sweden", i Social Science in Context. Historical, Sociological and Global Perspectives, Rickard Danell, Anna Larsson \& Per Wisselgren (red.), Lund 20I3, s. 78-92; Thom Axelsson, Rätt elev i rätt klass. Skola, begåvning och styrning 19ro-1950, Diss., Linköpings universitet 2007. Christina Hellblom-Thibblin, Kategorisering av barns "problem" i skolans värld. En undersökning av skolhälsovårdsrapporter läsåren 1944/45-1988/89, Diss., Uppsala universitet, 2004; Helena Hörnfeldt, Prima barn, helt ua. Normalisering och utvecklingstänkande i svensk barnhälsovård I923-2007, Göteborg 2009.

I8 Karin Zetterqvist Nelson \& Bengt Sandin, "Psychodynamics in child psychiatry in Sweden, 1945-85. From political vision to treatment ideology", History of Psychiatry 2013:24 (3), s. 312, 32I

I9 Det börjar dock komma fler studier, se t.ex. Peter Skagius, "Brains and psyches. Child psychological and psychiatric expertise in a Swedish newspaper, 1980-2008", History of the Human Sciences 2019:32 (3), s. 76-99. Internationellt är denna forskningsinriktning något mer utbredd, se t.ex. Juanne N. Clarke, "The portrayal of children's mental health and developmental issues from I89o to I920 in mass print magazines in North America", Children E Society 2016:3I (I), s. 36-47.

20 Mats Börjesson, "A newspaper campaign tells. The launch of neuro-psychiatric diagnoses in the Swedish daily press 1997-I999", Scandinavian Journal of Disability Research 1999:I (2), s. $3^{-25}$.

2I Linda Beckman \& Curt Hagquist, "Hur mår barn och ungdomar i Sverige? Analys av den officiella bilden, mediebilden och bilden från forskningen", Karlstad University Studies 2010:5, s. 23-44.

22 https://tidningar.kb.se/.

23 Beckman \& Hagquist, 20Io; Regeringens proposition 2007/08:IIo, s. I7-I9.

24 I denna artikel ligger vi närmast en summativ innehållsanalys med fokus på vilka ord som används och hur, se Hsiu-Fang Hsieh \& Sarah E. Shannon, "Three approaches to qualitative content analysis", Qualitative Health Research 2005:I5 (9), I 277-I 288. Se även Kristina Boréus \& Göran Bergström, "Innehållsanalys", i Textens mening och makt, Göran Bergström \& Kristina Boréus (red), Lund 2005, s. 77.

25 I figuren saknas vissa år. Detta innebär att vi inte hittat någon artikel under det året som vi kategoriserat som en larmartikel.

26 Dagens Nyheter 4/8 1969 "Föräldrar behöver prata om barns psykiska behov".

27 Dagens Nyheter I/9 1976 "Psykiska problemen ökar bland ungdomen".

28 Dagens Nyheter I4/5 1981 "Barnhälsovården: Försämringar väntas. Psykologer försvinner".

29 Dagens Nyheter 4/II I984 "Första stora undersökningen: Vart femte barn psykiskt stört".

30 Aftonbladet 15/2 I989 "Många lider av psykiska problem". 
3I Aftonbladet 8/9 I993"Fyra i varje klass är deprimerade. Ny undersökning visar att svenska ungdomar lider".

32 Svenska Dagbladet 3/2 1997 "Fler ungdomar söker psykhjälp. Sparkrav pressar skolor. Personalen hinner inte upptäcka elevers problem".

33 Svenska Dagbladet II/3 1996 "Psykiatrisk vård av unga ökar starkt".

34 Dagens Nyheter 3/Io 2004 "'Vart tionde barn söker psykhjälp'. Nya årsrapporten från BO: Försäljningen av antidepressiva läkemedel till tonåringar fördubblad på fem år”.

35 Dagens Nyheter 15/8 2006 "'Skolan ger inte de unga förmåga möta dagens krav'. Statlig utredning i dag: Tydligt samband mellan skolans brister och elevernas psykiska ohälsa".

36 Angående statistik som argument, se Tom Waidzunas, "Young, gay and suicidal. Dynamic nominalism and the process of defining a social problem with statistics", Science, Technology \& Human Values 2012:22 (2), s. 199-225.

37 Steven Ward, "Filling the world with self-esteem. A social history of truth-making", Canadian Journal of Sociology 1996:2I (I), s. I-23

$3^{8}$ Angående enrollering i vetenskap, se Bruno Latour, Science in Action, Cambridge I987, särskilt kap. 4, 5; för enrollering i media, se Staffan Wennerholm, "Unga forskare sökes'. Att tilltala vetenskapens påläggskalvar i teknikerbristens tidevarv", i Den mediala vetenskapen, Anders Ekström (red.), Nora 2004, s. I4I-I62.

39 Aftonbladet I2/I2 1982 "Var tionde pojke psykfall".

40 Dagens Nyheter $4 /$ II 1984 "Vart fjärde barn lever med ångest".

4I Aftonbladet 4/I I983"Är detta sanningen om våra barn? Övergivna. Olyckliga. Aggressiva".

42 Svenska Dagbladet 29/II 1982 "'Bara' ett av 20 barn stört".

43 Dagens Nyheter 4/r 1983 "Svenska tioåringar undersökta. Var tionde pojke har svåra psykiska problem".

44 Dagens Nyheter 4/II I984 "Första stora undersökningen: Vart femte barn psykiskt stört".

45 Dagens Nyheter 25/3 1986 "Studie från Norrbotten visar: Ungdomar blir sjuka av att gå arbetslösa".

46 Aftonbladet 6/3 199I "Fjärde världens barn".

47 Svenska Dagbladet II/3 1996 "Psykiatrisk vård av unga ökar starkt".

48 Svenska Dagbladet 2/4 1996 "Besparingar slår mot barns psykiska hälsa".

49 Svenska Dagbladet 23/2 I997 "Barnen far illa när föräldrarna blir arbetslösa".

50 Karin Zetterqvist Nelson, "Från samhällets barn till egna individer. Barnpsykiatrisk behandlingsideologi 1945-1985", Scandia 2012:78 (2), s. 56-57.

5I Aftonbladet 26/4 1996 "Ungdomarna sjuka av oro inför framtiden".

52 Beckman \& Hagquist 20IO, s. 29, 58.

53 Dagens Nyheter 2/4 200I "Långa köer till barn- och ungdomspsykiatrin. Prioritera barns hälsa”.

54 Svenska Dagbladet 4/3 2003 "Barn med psykproblem får inte hjälp i tid".

55 Aftonbladet $15 /$ IO 2002 "Dags att ta barnens stress på fullt allvar".

56 Svenska Dagbladet 28/6 200I "Allt fler unga mår sämre".

57 Svenska Dagbladet 5/10 2003 "Över en månads väntetid".

58 Även vuxnas psykiska ohälsa har kategoriserats som ett folkhälsoproblem i media, se Robert Ohlsson, "Public discourse on mental health and psychiatry. Representations in Swedish newspapers", Health 2018:22 (3), s. 302-303.

59 Svenska Dagbladet 28/6 200I "Allt fler unga mår sämre".

60 Dagens Nyheter 27/6 2002 "BO slår larm om dålig vård av unga: 'Två års kö av barnpsykiatri".

6I Dagens Nyheter I7/2 2005 "'Nödropen om självmord ökar från unga flickor'. Ny årsrapport 
från Bris: Konflikter i familjen vanligaste orsaken till att barn och ungdomar söker hjälper"; Dagens Nyheter $27 / 62005$ "'Psykiska ohälsan förvärras mycket bland svenska barn'. Stor ökning på varannan mottagning i barnpsykiatrin, visar ny rapport från Barnombudsmannen".

62 Dagens Industri 30/9 2005 "Ångest är de ungas nya arvedel".

63 Svenska Dagbladet $29 / 42007$ "Unga mår sämre än sina föräldrar. Fyra gånger fler försöker begå självmord - dubbelt så många är feta".

64 Dagens Nyheter 15/8 2006 "'Skolan ger inte de unga förmåga möta dagens krav'. Statlig utredning: Tydligt samband mellan skolans brister och elevernas psykiska ohälsa".

65 Dagens Nyheter 24/8 2005 "'Lärarna hjälplösa inför självmorden bland unga'. Lärarnas riksförbund angriper folkhälsominister Morgan Johansson: Sänkta krav i skolan löser inte problemen".

66 Se t.ex. Expressen 7/2 2006 "Fler barn känner sig stressade".

67 Se Karin Zetterqvist Nelson, "Debatten om bokstavsdiagnoser - en kamp om politiskt inflytande", i Barnets bästa. En antologi om barndomens innebörder och välfärdens organisering, Bengt Sandin \& Gunilla Halldén (red.), Eslöv 2003, s. IOI-I37.

68 Svenska Dagbladet 4/4 I984 "'Dagens barn mår bättre än vi tror".

69 Aftonbladet 05/06 2000 "Det var inte bättre förr. Forskare: Dagens barn och ungdomar mår minst lika bra".

70 Expressen 9/2 2008 "Bris siffror ingen anledning till panik".

7I Expressen 10/2 2008 "Sånt är livet".

72 Se Skagius 2019.

73 Vi fann endast en alarmerande artikel om neuropsykiatriska problem, Aftonbladet 23/II 2004 "Bara ett av fem barn med ADHD får diagnos".

74 Detta fann även Beckman \& Hagquist 20Io, s. 38.

75 Zetterqvist Nelson 2003.

76 Ian Hacking, "Statistical Language, statistical truth and statistical reason. The selfauthentication of a style of scientific reasoning", i The Social Dimensions of Science, Ernan McMullin (red.), Notre Dame 1992 s. I40-I53.

77 Ted Porter, Trust in Numbers. The Pursuit of Objectivity in Science and Public Life, Princeton 1996.

78 Jfr kontroversen om aids, se Joan H. Fujimura \& Danny Y. Chou, "Dissent in science. Styles of scientific practice and the controversy over the cause of AIDS", Social Science E̊ Medicine I994:38 (8), s. IOI7-Io36.

79 Se t.ex. Rose r999.

80 Se Briggs \& Hallin 2or6, s. 24, 47 för mer om subjektspositioner i media.

8I Karin Zetterqvist Nelson, "The changing construction of the child figure in literature on child psychotherapy in Sweden 1945-1975", i Childhood, Literature and Science. Fragile Subjects, Jutta Ahlbeck, Päivi Lappalainen, Kati Launis \& Kirsi Tuohela (red.), London 20I7, s. 74 .

82 Barns och ungas användning av psykologiska och psykiatriska termer är dock oftast komplex, se Peter Skagius, Anne-Li Lindgren \& Karin Zetterqvist Nelson, ”Psykisk ohälsa eller bara livet? Ungas egna beskrivningar av psykisk ohälsa i en internetbaserad stödverksamhet organiserad av och för ungdomar”, Socialmedicinsk Tidskrift 2018:95 (5), s. $568-576$.

83 Secord 2004, s. 655 . 